\title{
AC 2011-2623: IMPROVED TEAM FUNCTION: STUDENT-DRIVEN TEAM RULES AND CONSEQUENCES
}

\section{Peter J. Shull, Pennsylvania State University, Altoona Campus}

PETER J. SHULL is Professor of Engineering at The Pennsylvania State University. After a successful career in the technical field of Nondestructive Evaluation (NDE), and having worked at the prestigious Nation Institute of Standards and Technology, Dr. Shull made the decision to return to academia and began his career in education. From the first day, Dr. Shull noted an apparent lack of sound educational practice at the higher educational level. This is reflected in a statement made by Dr. Shull's Ph.D. advisor regarding teaching"If you know the material well, you'll be a great teacher!" Recognizing that one's degree of knowledge of a subject has no relationship to their understanding of pedagogy or their ability to apply it, over the past 12 years, Dr. Shull has maintained an active focus on sound pedagogy as related to engineering education. These efforts have been divided into understanding pedagogical theory and the pragmatic application into the classroom. His primary areas of focus are the ethics of caring, selfdetermination, and the connection of life skills to improved student learning.

He has authored numerous publications in the field of pedagogy and the technical area of NDE including the popular textbook entitled Nondestructive Evaluation: Theory, Technique, and Applications (Marcel Dekker, 2001), he is a Fulbright Scholar (Argentina2006), and is a member of the American Society of Nondestructive Testing, the American Society of Engineering Educators and the Institute of Electrical and Electronic Engineers. He received a B.S. degree (1982) in mechanical engineering from Bucknell University, Lewisburg, Pennsylvania, and a M.S. (1992) and a Ph.D. (1996) degree from The Johns Hopkins University, Baltimore, Maryland.

\section{Carla Firetto, The Pennyslvania State University}

Carla Firetto is a Ph.D. Candidate in Educational Psychology at Penn State. Her main interests are in the integration of multiple texts and the comprehension of multiple representations. She is currently also teaching as an adjunct faculty at Bucknell University.

\section{L.J. Passmore, Pennsylvania State University, Altoona Campus}




\title{
Team Function: Student-Driven Rules and Consequences
}

\begin{abstract}
The ability to effectively work in teams is a highly desirable quality in engineering graduates. Building these skills is essential to training students to participate successfully in the workplace. Further, given that much of engineering is taught in a team environment, how well the team functions is directly related to student learning of the course material.

Team dysfunction creates two significant consequences in the classroom. First, students do not learn the necessary elements to function well in a team. While college students can most often complete assigned tasks with even low functioning teams, they will not be able to do so in an industrial environment. Second, student learning of the topical material that the team is working on is reduced. When a few members, or an individual, decide to take over the completion of the assignments this creates a situation with a few students learning the material (those who completed the assignment) and the rest relying on group grading.
\end{abstract}

To increase both student understanding of the rules and consequences, and increase buy-in, at the beginning of the semester, students develop their own set of rules. This paper reports on the effect of team rules and the concomitant consequences that were developed by the students on team functioning.

Results of a multivariate analysis of variance shows that students perceived that they followed that rules significantly more than the other members of their group, that they were assigned more work than their peers, that they completed more work that their groups members, and the quality of their own work was higher. Interestingly, when asked about issues of rule-breaking that arose out of their groups, many individuals cited issues but ultimately failed to follow the agreed upon procedures for addressing those incidents.

Introduction

Teamwork has long been considered an important element of engineering education. The level of its importance is emphasized by team skills identified as one of the eleven ABET accreditation criteria required for an engineering program to be accredited-Criterion 3 Program Outcome d: an ability to function on multi-disciplinary teams. ${ }^{1}$ While there has been significant work on team development and structure, the area of team function that is related to behaviors is less studied or taught. ${ }^{2,3}$ When a team encounters interpersonal issues, it often degrades quickly to dysfunction. Typically, students will either informally disband and a few students will do the work for the group or the students will enlist the instructor to deal with the issue for them. Neither of these scenarios teaches students how to deal with these all too common issues.

In order to have a common understanding of what behaviors are acceptable and what are not, "rules" must be clearly spelled out, understood by all participants, and readily available for reference. The effectiveness of these rules can be enhanced by engaging the constituents in the process of development of the rules. ${ }^{4,5}$ This work looks at the effect of students' developing boundaries of acceptable group behavior and the consequences of breaking the "rules" and the adherence to those rules and consequences impacting group function. 


\section{Research Question}

The research question for this study asks: To what degree will students buy into a set of rules and consequences if they are actively involved in their creation? The level of buy-in is measured through student use of the rules and consequences to resolve team issues.

Setting and Participants

The participants in this study are a mix of engineering and engineering technology students who took Engineering Design and Graphics (EDSGN) or Computer Based I/O Systems (CBIOS) in the Fall 2010 at a small branch campus ( 4,000 students) of a large university in eastern United States. The campus environment is that of a small liberal arts school with a strong engineering program - the engineering technology program is the largest program on the campus.

The EDSGN course is a first year seminar course that meets 6 hours a week and is required in both the engineering and the engineering technology programs. The portion of the EDSGN course under study involves multiple student design projects - one lasting two weeks and another lasting 3 weeks. CBIOS is taught to all engineering technology students in their junior year. It consists of a common lecture for all sections of the course and separate laboratory experience for each section with a maximum of 16 students per section-76 students in 5 laboratory sections. For this work, the final two laboratory projects served as test period.

Table 1 shows the breakdown of the basic data for participants and team makeup. The team sizes ranged from 3 member teams to 5 member groups. The groups changed membership and size between the two projects. Group membership was set by instructor. There were a total of 113 students between the two classes. This would produce 226 surveys for the two projects. A total of 15 out of 113 students were excluded from the study -4 in EDSGN and 11 in CBIOS. Two were excluded for not doing one or more of the laboratory assignments. Twelve were excluded for failure to turn in survey sheets. One CBIOS student was excluded from the study for one of the projects because he worked as an individual on the final project. However, that same student did work on a team in the other project and was included for that portion. After excluding the aforementioned students, 196 surveys were considered valid and used in the data analysis.

Table 1. Participant and team makeup data.

\begin{tabular}{|l|l|l|l|l|}
\hline $\begin{array}{l}\text { Instructor/ } \\
\text { Class }\end{array}$ & Project & \# of Groups & $\begin{array}{l}\text { No. of } \\
\text { Students }\end{array}$ & Group Size \\
\hline $\begin{array}{l}\text { Instructor } 1 \\
\text { /EDSGN }\end{array}$ & $\# 1$ & 8 & 35 & $5-4$ person, 3-5 person \\
\cline { 2 - 5 } $\begin{array}{l}\text { Instructor } 2 \\
\text { /CBIOS }\end{array}$ & $\# 1$ & 12 & 37 & $11-3$ person, $1-4$ person \\
\cline { 2 - 5 } & $\# 2$ & 20 & 76 & $\begin{array}{l}3-3 \text { person, } 13-4 \text { person, } \\
3-5 \text { person }\end{array}$ \\
\hline Total & 4 & 59 & 74 & $\begin{array}{l}5-3 \text { person, 13-4 person, } \\
1-5 \text { person, } 1-1 \text { person }\end{array}$ \\
\hline
\end{tabular}

**Actual number of students is half this number as each student did two projects. 


\section{Research Methods}

Teamwork, like any other engineering topic, requires training. In advance of the rules/consequences assignment, students are given specific team training. While this is not the topic of this work, a very brief overview is useful. The training topics include communication skills, emotional intelligence, and team behavior type casting. The communication skills focus on elements of speaking that either inhibit or elicit functional communications. Simple versions are the difference between listening to understand versus listening to respond and judgment versus assessment. ${ }^{6}$ Integral to communication skills, students are introduced to emotional intelligence with an emphasis on emotional hijacking and its effects on team communication. ${ }^{7}$ The specific behavior type casting used creates three categories of different styles of behavior in a team environment - hitch hiker, couch potato, and enabler. ${ }^{8}$

Characteristics and specific behaviors of people in these categories are listed in Table 2. Students are introduced to these topics through specific active exercises that are designed to elicit personal experiences from which students can make a deeper and clearer connection to the concepts. Further, students put concepts to practice with significant feedback throughout the semester during their team based assignments.

Table 2. Characteristic and behaviors of the three classes of different team personalities.

\begin{tabular}{|c|c|c|}
\hline Hitch Hiker & $\begin{array}{l}\text { Couch Potato (Social } \\
\text { Loafers) }\end{array}$ & Enabler \\
\hline $\begin{array}{l}\text { Master of manipulation. } \\
\text { Rarely participates fully. } \\
\text { Often misses outside } \\
\text { meetings and deadlines. } \\
\text { Always has an excuse. } \\
\text { Argumentative when } \\
\text { held accountable. } \\
\text { Typically not well liked } \\
\text { by other group members. }\end{array}$ & $\begin{array}{l}\text { Fun to be around. } \\
\text { Will do what they are told to } \\
\text { do but only half heartily. } \\
\text { Very good at distracting the } \\
\text { group. } \\
\text { Does not argue when held } \\
\text { accountable. }\end{array}$ & $\begin{array}{l}\text { Often does very well in school. } \\
\text { Generally turns in quality } \\
\text { work on time. } \\
\text { Compensates for others not } \\
\text { doing their work. } \\
\text { Often does not trust others to } \\
\text { be part of the assignment. } \\
\text { Allows hitch hikers and couch } \\
\text { potatos to exist. }\end{array}$ \\
\hline
\end{tabular}

In this work, students used a common set of rules and concomitant consequences as a way to increase team functionality. (From here forward the use of the term rules will imply rules and consequences unless otherwise stated.) The students were introduced to the use of specific, common, and written rules of engagement in a team. The first exercise was for the students, working in their teams, to brainstorm and develop a set of their own rules. Each team posted their rules on the blackboard. The instructor discussed these rules with the class with the intent to look for common rules, clarification, and reduction of ambiguities. Using the entire list, the teams were then given the assignment of developing a final set due in the next class meeting. This procedure was repeated for all classes and sections involved in this study.

Using the compiled list from all teams, the two instructors developed a succinct set of rules that were used for all groups. Table 3 shows two of the rules used. The set was specifically designed to encompass as many of the rules developed by the teams. This was relatively easy as there was significant commonality among the different teams' rules even in the brainstorming process. The rules covered common team issues and the consequences ranged from warning for first time offences to no grade on the assignment to removal from the team. 
Table 3. Team rules and consequences. (For brevity only two of the rules are listed.)

\begin{tabular}{|l|l|}
\hline Rules & Consequences \\
\hline $\begin{array}{l}\text { If a team member is unable to attend lab they } \\
\text { must inform the project leader via text/email } \\
\text { at least } 24 \text { hours in advance. }\end{array}$ & $\begin{array}{l}1^{\text {st }} \text { offense: Warning } \\
2^{\text {nd }} \text { offense: No Grade on Project } \\
3^{\text {rd }} \text { offense: Dismissal from } \\
\text { Group }\end{array}$ \\
\hline Conversational stray will not be tolerated. & $\begin{array}{l}1^{\text {st }} \text { and } 2^{\text {nd }} \text { offense: Warning } \\
3^{\text {nd }} \text { offense }: \text { Cookies for Class }\end{array}$ \\
\hline
\end{tabular}

Students were given the master set of rules and provide with instructions on their use. To track significant issues students were to provide written documentation of the issue to all members of the team and copied to the instructor. The intent was to both create a clear paper trail to ensure clarity of what the issues were and to keep the instructor informed. When issues arose the team members were to use their general knowledge of solving team issue and apply the rules.

At the end of each laboratory assignment, the individual team members fill out a survey on the use of the rules. The survey, shown in Appendix A, covers questions regarding individual's use of the rules, adherence to specific rules such as attendance, distribution of workload, specific issues encountered and action taken, individual's comfort level with the use of the rules, team members tendency towards the three personalities (Table 2), and suggestions for improvement of the rules. All of the survey questions were quantitative except those related to specific issues encountered, actions taken, and suggestions for improvement which were open ended. The survey was designed such that each team member rated/review themselves and the other team members.

The responses to each qualitative question were reviewed for common thematic elements. These were converted to specific coding for each question and used to code the data. The data was then converted to pseudo-quantitative data by recording occurrences of each code.

\section{Results}

The survey in Appendix 1 was given to each student at the end of each of the projects. The survey was designed such that students rated the entire team including themselves. Thus, the data will include self and other. This includes the perceptions of the individual filling out the form of themselves and the perceptions those individuals have of the other members of their group, respectively. Of these, there were 196 valid self entries and 558 valid other entries for a total of 754 .

The results for survey questions 1 through 7 are shown in Table 4. The table is separated into response data for other (0) and self (1). The categories shown are N, the number of responses, the minimum and maximum response, the mean, and the standard deviation for each question. Abbreviations for the survey questions appear in the second column. The response for question 1 used a Likert scale of 1 (strongly disagree) to 5 (strongly agree). For questions 2, 3, and 6, the response is either "no" or "yes" which are indicated as 0 and 1 , respectively, in the minimum and maximum columns. Question 4 and 5 are related to the percentage of work assigned or performed. Question 7 asks students to assign a letter grade according to their 
perceptions of individual group members' performance. These A through $\mathrm{F}$ grades were converted to 5 through 1 , respectively.

Using the raw data in Table 4, we performed tests on between-subject effects. The analysis, shown in Table 5, calculates the effects between the individual's response, self, and the same individual's response to the other members of the team, other. In this 196 students scored themselves across the characteristics (survey questions $1-7$ ). Each of these students then scored the other members of their team for 558 different measurements yielding 754 total measurements.

Table 4. Survey descriptive statistics.

\begin{tabular}{|c|c|c|c|c|c|c|c|}
\hline \multicolumn{2}{|c|}{$\begin{array}{l}\text { Other }=0 \\
\text { Self }=1\end{array}$} & $\begin{array}{l}\text { Question \#/ } \\
\text { Description }\end{array}$ & $\mathbf{N}$ & Minimum & Maximum & Mean & $\begin{array}{l}\text { Std. } \\
\text { Deviation }\end{array}$ \\
\hline \multirow[t]{10}{*}{0} & \multicolumn{2}{|c|}{1 Followed Rules } & 578 & 1 & 5 & 4.46 & .955 \\
\hline & \multicolumn{2}{|c|}{2 Attended Lab } & 578 & 0 & 1 & .96 & .400 \\
\hline & \multicolumn{2}{|c|}{3 Attended Meetings } & 567 & 0 & 1 & .88 & .429 \\
\hline & \multicolumn{2}{|c|}{4 Percent of Work } & 575 & 0 & 50 & 25.40 & 6.664 \\
\hline & \multicolumn{2}{|c|}{ Assigned } & & & & 2403 & \\
\hline & \multicolumn{2}{|c|}{5 Percent of Work } & 575 & 0 & 70 & 24.93 & 8.895 \\
\hline & \multicolumn{2}{|c|}{ Performed } & 572 & 0 & 1 & 83 & 372 \\
\hline & \multicolumn{2}{|c|}{6 Work Done on Time } & 512 & 0 & 1 & & .372 \\
\hline & \multicolumn{2}{|c|}{7 Quality of Work } & 575 & 1 & 5 & 4.53 & .846 \\
\hline & \multicolumn{2}{|c|}{ Valid N (listwise) } & 558 & & & & \\
\hline \multirow[t]{9}{*}{1} & \multicolumn{2}{|c|}{1 Followed Rules } & 202 & 1 & 5 & 4.64 & .735 \\
\hline & \multicolumn{2}{|c|}{2 Attended Lab } & 202 & 0 & 1 & .96 & .449 \\
\hline & \multicolumn{2}{|c|}{3 Attended Meetings } & 198 & 0 & 1 & .91 & .425 \\
\hline & \multicolumn{2}{|c|}{$\begin{array}{l}4 \text { Percent of Work } \\
\text { Assigned }\end{array}$} & 201 & 10 & 60 & 27.36 & 6.562 \\
\hline & \multicolumn{2}{|c|}{5 Percent of Work } & 202 & 10 & 70 & 28.67 & 8.329 \\
\hline & \multicolumn{2}{|c|}{ Performed } & & & & & \\
\hline & \multirow{2}{*}{\multicolumn{2}{|c|}{$\begin{array}{l}6 \text { Work Done on Time } \\
7 \text { Quality of Work }\end{array}$}} & 201 & 0 & 1 & .88 & .331 \\
\hline & & & 202 & 3 & 5 & 4.70 & .531 \\
\hline & \multicolumn{2}{|c|}{ Valid N (listwise) } & 196 & & & & \\
\hline
\end{tabular}

Tests of between-subjects effects were performed using multivariate analysis of variance, see Table 5. They show that students perceived that they followed that rules significantly more than the other members of their group, $\left(\mathrm{F}(1,752)=4.835, \mathrm{p}=0.028, \eta^{2}=0.006\right)$, that they were assigned more work than their peers, $\left(\mathrm{F}(1,752)=10.254, \mathrm{p}=0.001, \eta^{2}=0.013\right)$, that they completed more work that their groups members, $\left(F(1,752)=22.462, p=0.000, \eta^{2}=0.029\right)$, and the quality of their own work was higher, $\left(F(1,752)=6.736, p=0.010, \eta^{2}=0.009\right)$. Of these, the largest effect was student perception that they completed more work than other members of their group. 
Table 5. Results for between-subjects (self and other) effects tests.

\begin{tabular}{|c|c|c|c|c|c|c|c|}
\hline Source & $\begin{array}{l}\text { Dependent } \\
\text { Variable }\end{array}$ & $\begin{array}{l}\text { Type III } \\
\text { Sum of } \\
\text { Squares }\end{array}$ & df & $\begin{array}{l}\text { Mean } \\
\text { Square }\end{array}$ & $\mathbf{F}$ & Sig. & $\begin{array}{l}\text { Partial } \\
\text { Eta } \\
\text { Squared }\end{array}$ \\
\hline Analysis & $\begin{array}{l}1 \text { Followed Rules } \\
2 \text { Attended Lab } \\
3 \text { Attended } \\
\text { Meetings } \\
4 \text { Percent of Work } \\
\text { Assigned } \\
5 \text { Percent of Work } \\
\text { Performed } \\
6 \text { Work Done on } \\
\text { Time } \\
7 \text { Ouality of Work }\end{array}$ & $\begin{array}{l}3.834^{\mathrm{a}} \\
.084^{\mathrm{b}} \\
.092^{\mathrm{c}} \\
438.424^{\mathrm{d}} \\
1661.619^{\mathrm{e}} \\
.277^{\mathrm{f}} \\
3.906^{\mathrm{g}}\end{array}$ & $\begin{array}{l}1 \\
1 \\
1 \\
1 \\
1 \\
1 \\
1 \\
1\end{array}$ & $\begin{array}{l}3.834 \\
.084 \\
.092 \\
438.424 \\
1661.619 \\
.277 \\
\\
3.906\end{array}$ & $\begin{array}{l}4.835 \\
1.301 \\
.867 \\
\\
10.254 \\
\\
22.462 \\
\\
2.237 \\
6.736\end{array}$ & $\begin{array}{l}.028 \\
.254 \\
.852 \\
.001 \\
.000 \\
.135 \\
.010\end{array}$ & $\begin{array}{l}.006 \\
.002 \\
.001 \\
.013 \\
029 \\
\\
003 \\
\end{array}$ \\
\hline
\end{tabular}

Students were free to express their perceived issues and how they addressed these via open ended questions. The qualitative data was coded for types of issues and methods of addressing the issues. The frequency of the number of issues cited per student is presented in Table 6 , and how the students addressed the issues that arose are noted in Table 7.

Table 6. Frequency of issues per student.

\begin{tabular}{|l|c|c|c|c|c|}
\hline & $\begin{array}{l}\text { No. of issues } \\
\text { cited/student }\end{array}$ & Frequency & Percent & $\begin{array}{l}\text { Valid } \\
\text { Percent }\end{array}$ & $\begin{array}{l}\text { Cumulative } \\
\text { Percent }\end{array}$ \\
\hline Valid & 0 & 79 & 38.2 & 39.3 & 39.3 \\
& 1 & 55 & 26.6 & 27.4 & 66.7 \\
& 2 & 32 & 15.5 & 15.9 & 82.6 \\
& 3 & 27 & 13.0 & 13.4 & 96.0 \\
& 4 & 8 & 3.9 & 4.0 & 100.0 \\
Missing & Total & 201 & 97.1 & 100.0 & \\
Total & & 6 & 2.9 & & \\
\hline
\end{tabular}

Table 7. Methods used to address student issues.

\begin{tabular}{|l|c|}
\hline $\begin{array}{l}\text { How issue was } \\
\text { addressed }\end{array}$ & $\begin{array}{l}\text { Number } \\
\text { addressed in that } \\
\text { manner }\end{array}$ \\
\hline No Issue & 96 \\
\hline Not Addressed & 20 \\
\hline Talked No Resolution & 33 \\
\hline Talked with Resolution & 41 \\
\hline Used Rules Effectively & 7 \\
\hline Used Rules Ineffectively & 8 \\
\hline Instructor Involvement & 2 \\
\hline
\end{tabular}




\section{Discussion}

Previous research has shown that the introduction of ground rules can increase student learning. ${ }^{9}$ Further, other work shows results that support the use of student-generated rules to enhance the quality of discourse between team members. ${ }^{4}$ The results of the current study, which combines the use of rules with student engagement in their development, are of mixed success.

The results for the data of between-subjects (Table 5) are not entirely unexpected. These results can be explained by halo-bias where individuals rate themselves as performing better than others in a group is not uncommon. ${ }^{10}$ Although halo-bias is highly dependent on the instrument used and on the topic, in this work it is the most probable cause of the difference. ${ }^{11}$ This belief that the each individual completed more work than the rest on aggregate would lead to the notion that more than $100 \%$ of the work was done. This could clearly lead to an increased number of issues (particularly if the results were not of high quality.) Further, it may not be important if these issues are real or not. Simply holding the notion that "I did more than my share." can have a negative impact on team function. ${ }^{12,13}$ Given the likelihood for frustration from this scenario has significant potential to augment issues or even create them.

Out of 201 responses to what issues occurred (Question 8), 38.2\% (79) of the students specifically indicated that no issues occurred. While this is an encouraging that $40 \%$ of the students performed in a team environment at or near the end of the semester without issues, $\sim 60 \%$ (122) had at least one issue. Further 33.3\% (67) of the students listed more than one issue.

The notion of using student generated rules was to help address student issues by providing a clear process for working through the dysfunction. The data shows only a few instances $(<15 \%)$ of students directly cited using the rules and of these only about half resulted in their effective use. However, students cited talking about the issue with a positive outcome (issues resolved) as the most common method for dealing with issues. This was not recorded as a use of the rules for two reasons. First, the specific issue and method of solution were not clearly linked in the survey enough to see a clear use of the rules and second, there was no record of rule violation/issue or implementation of the consequences such as a warning. The rule process required students to document issues in writing and copy these to the instructor. Only a few students properly documented their issues. Nonetheless, we note that student-initiated talking about issues was effective and widely used.

Student use of the rules effectively or even cursorily seems to be an issue. The response rate for Question 1 (use of rules) shows students claim to use the rules resulting in a mean of 4.46 out of 5 when rating themselves and 4.46 when rating other team members. Yet out of the $60 \%$ that cited issues only a small percent cited using the rule and only half of these were successful. Further, many of these did not document the issues. Even those that resolved the issue through talking, few of them had any form of documentation.

Conclusions and Future Work

Students generated a set of rules and concomitant consequences to clarify acceptable and unacceptable behavior in a team setting. The design of the rules produced a clear process on 
how to handle most common issues encountered in a student team. The findings show that overall students did not participate in the process of using the rules that they developed. This was not a question of students not having issues; as the majority did have at least one issue and many had multiple issues. However, while most students did not clearly use the rules when issues arose, many were able to resolve their issue by just talking. This method did not complete the requirement of rule use as the students did not document the event.

One of the questions that needs to be address is why students are often unwilling to use their own rules. This work clearly shows that students do have issues that are interfering with effective function in their group. Given the number of students who did not address their issues at all or talked about the issue but did not complete the documentation portion, it would be instructive to better understand the cause of the reluctance to effectively engage in student generated rules. 


\title{
Appendix 1 Survey instrument. (Survey has been condensed to reduce space.)
}

Name each member of your group (including yourself) in ALPHABETICAL ORDER (by first name then last name). If you have more than 5 members in your group just add letters to each group/question. You will refer to this order for each of the following questions.

a.

b.

c.

Rate the members of your team (including yourself) for each of the following statements. You do not need to write the individual names for each question, but make sure the letter for each individual corresponds to the letter for the individual identified above (keep the same order).

1) Followed all of the agreed upon rules. (1 to 5: 1 strongly disagree -5 strongly agree)

a.

b.

C.

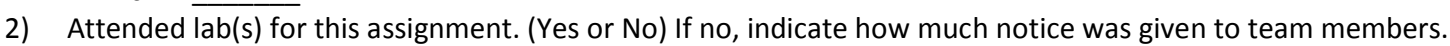

a. never

b.

c. How much notice? (1) more than $24 \mathrm{hr}$ (2) less than $24 \mathrm{hr}$ (3) after lab or

How much notice? How much notice?

3) Attended all outside meetings. (Yes or No) If no, indicate how many and how much notice was given to team members.
a. missed out of How much notice? (1), (2), or (3) from Question 2
b. - missed out of
c. missed out of How much notice? How much notice?

4) Each team member was assigned what percentage of the project's work. (0-100\%) Make sure your total equals 100.
a.
b.
c.
$=\frac{100}{100}$

5) Each team member completed what percentage of the project's work. (0-100\% ) Make sure your total equals 100.
a.
b.
c.
$=100$

6) Team member completed their portion of the work 24 hours prior to the submission deadline. (Yes or No)

a.

b.

c.

7) Grade the quality of the work submitted by each of the team members. (A, B, C, D, or F)

a.

b.

C.

Having answered these questions we hope you can now identify issues related to team function on this project.

8) Please identify in detail any issues related to team function that your group has experienced during this project.

9) What have you done to address these issues?

10) Rate the members of your team as to their tendency to fall into each of the three categories (Hitch Hiker $(\mathrm{HH})$, Couch Potato $(C P)$, or Enabler (E)). (1-5, 1 not at all, to 5 very much)
$(1-5)$
$(1-5)$
(1-5)
Hitch hiker $(\mathrm{HH})$
Couch Potato (CP) Enabler (E)

\begin{abstract}
a.
c.
\end{abstract}

b.




References

1. Program Evaluation Form URL: http://www.abet.org/Linked\%20DocumentsUPDATE/PEV\%20Docs/TAC/T004\%20PEV\%20Report\%2005-30-08.doc

2. Vincent Roousseau, Caroline Aube, and Andre Savoie, "Teamwork Behaviors: A Review and Integration of Frameworks," Small Group Research, V. 37, No. 5, 2006, pp. 540-570.

3. Michael Brannick and Eduardo Salas, Team Performance and Assessment Measurements, NJ, Taylor and Fransis, 2009, pp. 19-45.

4. Kathryn Bullen, Kirsty Moore, and Jennifer Trollope, "The Influence of Pupil-generated Ground Rules on Collaborative Leaning in the Classroom: A Pilot Study," Evaluation and Research in Education, V. 16, No. 4, 2002, pp. 202-217.

5. Judi McLean-Parks, Li Ma, and Daniel G. Gallagner, "Elasticity in the 'rules' of the game: Exploring organizational expedience, “ J. of Human Relations, V. 63, No. 5, 2010, pp. 701-730.

6. V. Satir, Satir step by Step: A Guide to Creating Change in Families, Science and Behavior Books, Palo Alto, CA, 1983.

7. D. Goleman, Emotional Intelligence, Bantam Books, NY, NY, 1995.

8. B. Oakley, "It Takes Two to Tango: Why 'Good' Students Problematic Behavior in Teams," Journal of Student Centered Learning, Volume 1, Issue 1, 2002, pp. 19-27

9. L. Dawes, E. Fisher, and N. Mercer, "The Quality of Talk at the Computer," Language and Learning, V. 22, No. 3, 1992, pp. 22-25.

10. Phil Rosenzweig, Halo Effect... and Eight Other Business Delusions that Deceive Managers, Free Press, NY, NY 2007, pp.18-52.:

11. Paul E. Spector, "Method Variance as an Artifact in Self-Reported Affect and Perceptions at Work: Myth or Significant Problem?"," Journal of Applied Psychology, V 72, No. 2, 1987, pp. 438-443.

12. Larry W. Anders, Edward F. Centofante, and James T. Ott, "Building the Instructional Team for Effective Leadership,” NASSP Bulletin Nov 1987, 71 pp. 61-63.

13. Praveen Aggarwal and Connie L. O'Brian, "Social Loafing on Group Projects: Structural Antecedents and /Effect on Student Satisfaction," Journal of Marketing Education, Vol. 30, 2008, pp. 255-264. 